\title{
LOTZE AND THE EARLY CAMBRIDGE ANALYTIC PHILOSOPHY
}

\begin{abstract}
"This summer I've read about a half of Lotze's Metaphysik. He is the most delectable, certainly, of all German writers - a pure genius."
\end{abstract}

William James, September 8, $1879 .{ }^{1}$

Summary

Many historians of analytic philosophy consider the early philosophy of Moore, Russell and Wittgenstein as much more neo-Hegelian as once believed. At the same time, the authors who closely investigate Green, Bradley and Bosanquet find out that these have little in common with Hegel. The thesis advanced in this chapter is that what the British (ill-named) neo-Hegelians brought to the early analytic philosophers were, above all, some ideas of Lotze, not of Hegel. This is true regarding: (i) Lotze's logical approach to practically all philosophical problems; (ii) his treating of the concepts relation, structure (constructions) and order; (iii) the discussion of the concepts of states of affairs, multiple theory of judgment, general logical form; (iv) some common themes like panpsychism and contemplating the world sub specie aeternitatis.

\section{LOTZE, NOT HEGEL, LIES AT THE BOTTOM OF CAMBRIDGE ANALYTIC PHILOSOPHY}

Conventional wisdom has it that the early philosophy of Moore and Russell was under the strong sway of the British "neo-Hegelians". In the same time, however, those historians who investigate the British "neo-Hegelians" of 1880-1920 in detail, turn attention to the fact that the latter are not necessarily connected with Hegel: William Sweet made this point in regard to

\footnotetext{
${ }^{1}$ Perry (1935), ii, p. 16.
} 
Bosanquet, ${ }^{2}$ Geoffrey Thomas in regard to Green, ${ }^{3}$ and Peter Nicholson in regard to Bradley. ${ }^{4}$ Finally, Nicholas Griffin has shown that Russell from 1895-8, then an alleged neo-Hegelian, "was very strongly influenced by Kant and hardly at all by Hegel". 5

These facts are hardly surprising, if we keep in mind that the representatives of the school of T. H. Green - Bradley, Bosanquet, W. Wallace, R. L. Nettleship —were called "neo-Hegelians" only by their opponents. Apparently, that term did not have any descriptive value from the very beginning. Indeed, the four authors mentioned above were only named so because "they had some knowledge of Hegel, and a good deal more of Kant. The fact of their having this knowledge was used by their opponents ... to discredit them in the eyes of a public always contemptuous of foreigners." The "neo-Hegelians" themselves repudiated this title decisively.

For scholars well-versed in German philosophy of the nineteenth century, the claim that the mainstream British philosophy of 1870-1910 was "Hegelian" is rather puzzling. The point is that after 1840, there was scarcely any German philosopher of importance who would openly declare that he was Hegelian. The reason for this was that in the 1840s, Hegelianism was seen as a spectacular flop due above all to new scientific discoveries which had shown that many of Hegel's speculations were simply mistaken. So the question arises: were the leading philosophers in Britain so ill-informed about this development that between 1870 and 1910 they embraced Hegelianism as their philosophical credo? There are pieces of evidence which show that this cannot be the case. In 1877, for example, Wilhelm Wundt had informed his British colleagues in the newly founded Mind that the Hegelian school had "at the present day the fewest thoroughgoing adherents [in Germany]."7

Be this as it may, it is beyond any doubt that the early Cambridge analytic philosophy was formed under massive Teutonic influence. One of the few who already noticed this in the 1950s was John Passmore. In Hundred Years of Philosophy he devoted considerable space to the philosophy of Sigwart and Lotze, Herbart and Ueberweg. What was published on them in the book, however, was only "a residue of a much more expanded account which [unfortunately enough] Arthur Prior had persuaded [him] to castrate".

\footnotetext{
${ }^{2}$ Cf. Sweet (1995).

${ }^{3}$ Cf. Thomas (1987), pp. 45-54.

${ }^{4}$ Cf. Nicholson (1990).

${ }^{5}$ Griffin (1996), p. 215.

${ }^{6}$ Collingwood (1939), p. 16.

${ }^{7}$ Wundt (1877), p. 511.

${ }^{8}$ Passmore (1995), p. 194.
} 
In this chapter we are going to show that Rudolf Hermann Lotze (1817-1881) was not just one among many other powerful German philosophers from about 1880-1920 who influenced their colleagues in Britain. He was clearly the leading figure among them.

\section{WHY ARE THE BRITISH IDEALISTS BELIEVED TO BE HEGELIAN?}

If, however, the leading fin de siècle British philosophers were not really Hegelian but Lotzean, why did they believe this misconception? Mainly for three reasons: First of all, because Lotze himself can easily be interpreted as a Hegelian. The issue is the method of eclecticism which Lotze followed. Indeed, from the very beginning, his slogan was: "When we cannot necessarily join one of the dominating parties, we [shall ...] stay in the middle via free eclecticism." This method meant that Lotze used the ideas of different philosophers, but above all of Kant, Fichte, Schelling, and also Hegel, distilling the most valuable among them and formulating them in an exact form. This explains why one so easily discerns Hegel's ideas in Lotze's writings.

Secondly, Russell's teachers at Cambridge, G. F. Staut and James Ward, were widely believed to be Hegelian. In truth, though, they were under the direct influence of Lotze. ${ }^{10}$ This is shown by the fact that Lotze was one of the philosophers set for examinations at Cambridge between 1890 and 1910. Indeed, Moore later remembered that Ward encouraged him "to read pieces of Lotze's Metaphysic and to write essays on these pieces [which] then [... Ward] discussed privately with [him]." ${ }^{11}$ Furthermore, towards the end of this period, C. D. Broad won the Burney Prize with an essay on Lotze's Philosophy of Religion. ${ }^{12}$

Thirdly, the philosophers who most influenced the young Moore and Russell through reading, the alleged neo-Hegelians Bradley and Bosanquet, were also mainly under Lotze's

\footnotetext{
${ }^{9}$ Lotze (1843), p. 1. Today the word "eclecticism" is only used and understood in a pejorative sense. It is astonishing how successfully Lotze used this method. How he managed to do this will be discussed presently. It is interesting to note that Lotze showed admiration towards eclecticism already in his pre-theoretical period: in 1840 he wrote the poem "Eclecticism". Cf. Kroneberg (1899), p. 218.

${ }^{10}$ This is especially true of Ward, who studied with Lotze in Göttingen in 1870. Note that in comparison to his two other teachers at Cambridge, Sidgwick and Stout, Ward exercised the strongest influence on Russell. Cf. Griffin (1991), p. 35.

${ }^{11}$ Moore (1942), p. 17.

${ }^{12}$ Kuntz (1971), p. 57.
} 
sway. This should be no surprise since their teacher, Thomas Green, was so enthusiastic about Lotze that in 1880 he started a large project to translate his System of Philosophy into English; this included Lotze's Logic (1874) and Metaphysic (1879). ${ }^{13}$ After Green's demise two years later, this project was continued by a team under the guidance of Bosanquet. Besides Green and Bosanquet, A. C. Bradley (brother of F. H. Bradley), R. L. Nettleship and J. Cook Wilson took part in the general editing. The other British "neo-Hegelian" who directly influenced Moore and Russell-J. M. E. McTaggart (b. 1866) — was too young to take part in this translation. The two volumes appeared in English in $1884 .{ }^{14}$

At the same time, in Cambridge James Ward and Henry Sidgwick were instrumental in preparing the translation of Lotze's three volumes of Microcosm by Elisabeth Hamilton and E. E. Constance Jones. The book itself was published in $1885 .{ }^{15}$

Now the fact that Lotze decisively influenced Russell's Cambridge teachers in philosophy explains why Russell, who was sure for years that he was a "neo-Hegelian", was shocked when he read Hegel in the original for the first time in June $1897 .{ }^{16} \mathrm{He}$ found that Hegel's writings substantially deviate from his own standard of exactness. In fact, what he liked in the "neo-Hegelians" were, above all, some points of Lotze's philosophical logic assimilated in their writings, as well as the Lotze-style relationism. We are going to discuss them in the next section.

\section{LOTZE'S INFLUENCE ON THE BRITISH PHILOSOPHERS}

Lotze influenced the British Idealists mainly in two directions: by the introduction of philosophical logic, and by underlining the importance of relations:

(i) Philosophical Logic. As rightly noted by Agnes Cuming, what Bradley and Bosanquet accepted from German philosophy were, above all, some ideas from Lotze's philosophical

\footnotetext{
${ }^{13}$ Green said once to Bosanquet: "The time which one spent on such a book as that (the Metaphysic [of Lotze]) could not be wasted as regards one's own work." Lotze (1888), p. v.

${ }^{14}$ Cf. Lotze (1884).

${ }^{15}$ Cf. Lotze (1885).

${ }^{16} \mathrm{Cf}$. chapter $6, \S 6$.
} 
logic: ${ }^{17}$ "Their treatment of the problems of logic is almost a continuation from the point at which the German writer left off." 18

Incidentally, around 1910, the prominence of Lotze's philosophical logic was widely accepted in Europe. Thus in 1912 Heidegger called Lotze's Logic "the basic book in modern logic". ${ }^{19}$ A few years later, the neo-Kantian Bruno Bauch wrote: "Of everything that has followed in the area of logic from Hegel to the present day, there is nothing that has surpassed Lotze's logical achievements in value. ${ }^{20}$ We must keep in mind that in the 1910s Bruno Bauch was a colleague of Frege in Jena, and one of his few admirers. This, however, was not a hindrance for him to declare Lotze the most prominent among the logicians.

Unfortunately, after 1920 the awareness of the importance of Lotze's logic downed and this to such an extent that in the standard The Development of Logic of William and Martha Kneale, ${ }^{21}$ the name of Lotze was not even mentioned.

One of the reasons for the demise of interest in Lotze's logic is that very often the discoveries in philosophical logic are anonymously assimilated. This means that because, being technical, they are absorbed like an anonymous meme, without being necessarily connected with the person who advanced them. This explains why Bradley, a man who, according to all considerations, was strongly influenced by some ideas from German philosophy, "had no high opinion" of German philosophy as such. ${ }^{22}$ Moreover, the discoveries in this branch of learning spread very quickly and were widely accepted in a short time. A typical example in this respect is the context principle, rediscovered by Lotze as early as in the $1840 \mathrm{~s}^{23}$ Vehemently criticised by both Hegel and Mill, "the slogan 'Only in the context of a proposition [or judgment] do words have meaning' [... became] an Anglo-Hegelian commonplace" after 1875, assumed also by Green and Bosanquet. ${ }^{24}$

The main reason why philosophers lost interest in Lotze's logic, however, was the introduction of a new paradigm of theoretical reasoning in the 1920s, the main characteristic of which was the schism between continental and analytic philosophy. Suddenly, many im-

\footnotetext{
${ }^{17}$ We are going to show why Lotze's logic was philosophical in $\S 4$.

${ }^{18}$ Cuming (1917), p. 165.

${ }^{19}$ Heidegger (1978), p. 23 n..

${ }^{20}$ Bauch (1918), p. 45.

${ }^{21}$ Cf. Kneale (1962).

22 Taylor (1925), p. 7.

${ }^{23}$ On the history of the context principle see Milkov (1997), ii, p. 541.

${ }^{24}$ Manser (1983), p. 62.
} 
portant achievements of the late nineteenth century philosophy lost their significance or were disguised in new forms.

(ii) Relationism. The second point of influence of Lotze upon the British philosophers was his relationism (which we are going to discuss in $\S 5$ ). To be sure, before Lotze, relations were "neglected as largely subjective, and of dependent or related becoming". ${ }^{25}$ After Lotze's "objectivist turn" (discussed in $\S 5$ again), relations gained a central position in philosophy.

In Britain Lotze's translator T. H. Green first put relations into the centre of philosophical discourse: He accepted that reality is relational. ${ }^{26} \mathrm{~F}$. H. Bradley tried to disprove this thesis. Indeed, a central theme in Appearance and Reality (1893) was a "general criticism of relations" and the demonstration that they are only appearances. Some years later Russell articulated his turn from a monistic idealism into atomistic realism as criticism of this thesis.

\section{LOTZE AND THE LOGICALIZATION OF PHILOSOPHY}

Lotze believed that "after centuries of philosophical work it is impossible to suggest new ideas. ${ }^{, 27} \mathrm{He}$ saw his task as an examination of the old ideas in philosophy from new perspectives. In fact, this was how his programme for eclecticism functioned.

More especially, Lotze's objective was to give a new meaning to some specific philosophical ideas introduced in philosophy after 1781 (the year of publishing of Kant's $C P R$ ). In particular, he started to present them as problems of logic. In this way, Lotze continued the logical turn in metaphysics started by Kant, which eventually made metaphysics a formal science. $^{28}$

The fruit of Lotze's idiosyncratic method was a number of concepts newly introduced—or merely revived - in philosophy which are still widely discussed today. Here are some of them: the concept of value in logic (its most notorious successor was the concept of truth-value); the objective content of judgment - a theory later developed in the idea of radical distinction between subject and object of knowledge; the already mentioned context principle; the notion

\footnotetext{
${ }^{25}$ Kuntz (1971), p. 38.

${ }^{26}$ This point explains Bosanquet's claim: "These two distinguished men [Lotze and Green], however different in method and style of thought, had some fundamental tendencies in common." Lotze (1888), p. v.

${ }^{27}$ Becher (1929), p. 51.

${ }^{28}$ Cf. chapter 4.
} 
of state of affairs (Sachverhalt), ${ }^{29}$ central to the philosophy of both Husserl and Wittgenstein; ${ }^{30}$ the notion of objective content of perception (its most notorious successor was the concept of sense-data ${ }^{31}$ ).

Unfortunately, Cambridge analytic philosophers did not follow another idea of Lotze (in which he actually followed Schleiermacher and also Trendelenburg). This was "the objective study of the earlier achievements in philosophy", ${ }^{32}$ the detailed, minute study in history of philosophy. In other words, the Cambridge program for rigorous philosophy did not include a sub-program for minute analyses in history of philosophy. ${ }^{33}$ Among analytical philosophers in Britain, this was only started to be done in the late 1960s, above all by Michael Dummett in his books on Frege's philosophy. ${ }^{34}$

Many of the concepts Lotze introduced, or revived, in philosophy were further assimilated by Lotze's student Frege (indeed, Frege attended at least one of Lotze's lectures in Göttingen, and, as it is clear from "17 Key Sentences on Logic", knew the second edition of Lotze's Logic very well ${ }^{35}$ ) and today are mainly associated with Frege's name. However, in this chapter we will not be concerned with Lotze's influences on Frege. ${ }^{36}$ Indeed, this is a huge theme that can be comprehensively investigated only in a monograph. Rather, we will only concentrate on the influence of Lotze's extensive logicalization of philosophy on the Early Cambridge analytic philosophy: on Russell, Moore and Wittgenstein.

\section{LOTZE'S "CONNECTIONISM"}

Lotze's philosophy can be also defined as a type of objectivism. Closely following Trendelenburg and in the last reckoning Schleiermacher, he advanced a philosophy which did not start from the subject. Instead, he suggested a form of "connectionism"-connectionism not in the sense of the contemporary philosophy of mind of Paul Smolensky, however, but in

\footnotetext{
${ }^{29}$ On Lotze as the originator of this concept see chapter 7.

${ }^{30}$ Apparently, Wittgenstein borrowed the terminology of Sachverhalte from Adolf Reinach, a follower of Husserl. Cf. on this point B. F. McGuinness (2002), p. 171.

${ }^{31}$ To be discussed in chapter 12 .

${ }^{32}$ Stumpf (1910), p. 166.

${ }^{33} \mathrm{Cf}$. chapter 2.

${ }^{34}$ Cf. Dummett (1973), (1981), (1991).

${ }^{35}$ On Lotze's influence on Frege cf. Sluga (1980), p. 45.

${ }^{36}$ Cf. Gabriel (1984), (1989a), (1989b).
} 
the sense that Lotze studied the "general inner connection of all reality"- "the connection passing throughout all reality." (Lotze 1879, §§ iii, iv) The ontological points of the universe - the substances (the things) - are nothing but the tying knots (die Kraftpunkte) of different systems of such connections. Lotze related them "to optical instruments which reflect ... not convertible beams in a direction which they themselves cannot follow" (Lotze 1841, 232).

Central concept in Lotze's connectivist ontology was relation. He used to repeat: "It belongs to the notion and nature of existence to be related." (Lotze 1885, ii, 587) Lotze was convinced that the category of relation is what unites all philosophical theories. Moreover, he embraced this thesis because he believed that "all who search for truth of any sort, believe in an order of things". 37

In the literature Lotze's connectionism was described in a variety of ways. P. G. Kuntz, for example, presented Lotze's metaphysics as a Theory of Order. To be more specific, Lotze was interested not in formal order, but in concrete, "actual series, networks of series, causal regulations, analogies, and processes that are encountered, not merely thought". ${ }^{38}$ Other authors insisted that Lotze's "philosophy is essentially an analysis of the concept of mechanism of the nature"; $; 9$ of the concept of all-embracing causal connection. It accepted that the particulars of our experience are connected with all other elements through a lawful connection.

Apparently, Lotze's philosophy advanced that kind of objectivism on the basis of which the philosophy of logical constructivism —of all that Aufbau programs from 1910s-1920swas later set up. This programme was embraced by all early Cambridge analytic philosophers but not only by them: it also influenced Carnap and other Vienna philosophers and sociologists around 1930, for example, Alfred Schütz. ${ }^{40}$

\section{LOTZE AND RUSSELL}

\footnotetext{
${ }^{37}$ Kuntz (1971), p. 26. Georg Misch had once noted (cf. Misch 1912, p. xxix) that in accepting relationism, Lotze followed Kant. Moreover, in an authentically Kantian manner, he subjugated the general concepts of philosophy to scientific ones. Indeed, Lotze's relationism followed the tendency in Kant to consider scientific concepts relational, which he apparently borrowed from d'Alambert and Lagrange.

${ }^{38}$ Kuntz (1971), p. 29.

${ }^{39}$ Höffding (1896), ii, p. 571.

${ }^{40}$ Cf. Schütz (1932).
} 


\subsection{Opening}

That connectionism and Lotze-style relationism lies at the bottom of Russell's project for New Philosophy is clearly seen in Russell's The Principles of Mathematics, to which a Lotzean subtitle can be given: "A Study of Order". Indeed, it investigates the order in space (Part VI) and the order in time (Part VII). The only conception that is not discussed by Lotze, but which lies at the centre of Russell's attention, is the order in mathematics. The reason for this is simple. While Lotze accepted logic as setting up the foundations of mathematics (for him "mathematics develops as a branch of general logic", so that "the fundamental ideas and propositions of mathematics have their systematic place in logic" $\left.{ }^{\circ 1}\right)$, he was against the formalisation of logic. Lotze saw in it an "addiction of thinking" which is attractive not because of the value of the scientific results themselves, but because of the exactness of the results to which it leads. ${ }^{42}$ For this position he was severely criticised early on by Russell in An Essay in the Foundations of Geometry. ${ }^{43}$

\subsection{Lotze's general influence on Russell ${ }^{44}$}

That in 1895-8 Russell was much more neo-Lotzean than neo-Hegelian is clearly seen from the following facts:

(i) The philosophers who directly influenced Russell most in this period-Helmholtz, Stumpf, Erdmann - were all strongly influenced by Lotze. Russell also followed Lotze's teachers: Herbart and, ultimately, Kant.

(ii) Russell already embraced the anti-psychologism in his first printed review. ${ }^{45}$ Indeed, today it is widely accepted that "Bradley's attack on psychologism was [...] by far and away [his] most important contribution to modern logic". ${ }^{46}$ We must remember, however, that the

${ }^{41}$ Lotze (1874), §18. Sluga sees in this an ancestor of Frege's logicism: "Among the many things that Frege owes to Lotze, the most important is perhaps the idea of logicism." Sluga (1980), p. 57. This, however, is scarcely the case. The program of logicism had its sources in the development of mathematics in the last quarter of the twentieth century.

${ }^{42}$ Cf. Lotze (1843), p. 2. In support of non-formal exposition of logic Lotze explicitly refers to Trendelenburg.

${ }^{43}$ Russell (1897a), p. 96.

${ }^{44}$ Lotze's concrete influence on Russell is discussed in the next chapter.

${ }^{45}$ Russell (1895).

${ }^{46}$ Griffin (1996), p. 216. 
"father of the criticism of psychologism" was Lotze, ${ }^{47}$ not Bradley. To be sure, Lotze developed this program for anti-psychologism by 1841-43, before Bradley was even born.

(iii) Russell embraced the relationism which, as already seen, was also central to T. H. Green and F. H. Bradley. Indeed, Russell already spoke of "space as relational, and of spatial figures as relations" in An Essay in the Foundations of Geometry. ${ }^{48}$

\subsection{Russell's alleged disagreement with Lotze}

It is true that Russell disagreed with some specific theses of Lotze, especially with two of them:

(i) Russell's general disagreement was connected with Lotze's alleged conception that the points are factual—not absolute. As a consequence, Lotze allegedly did not accept autonomous relations; instead, he claimed that relations are functions of the points between which they stand. Russell insisted that Lotze's conception arises "from neglect to observe the eternal self-identity of all terms and logical concepts, which alone form the constituents of propositions". 49

In truth, Lotze's position on this point was not thus one-sided as Russell believed it to be. Ontologically, Lotze did assume that external relations have priority over the things they connect. As a result, he accepted a form of atomism. This claim can be supported by the fact that many writers, for example, Harald Höffding, treat Lotze as an atomist. ${ }^{50}$ Anthony Manser accepts the same. According to this author, Lotze assumed that "what is complex in our mental life must be constructed out of simple atoms". ${ }^{51}$

(ii) Similarly, Lotze's position on the following question: "Are there absolute points of space and moments of time?" is much more intricate than Russell presented it. In fact, Lotze claimed that the things are "at least participants in immutable independent being, and present the fixed points to which is attached, in whatever way, the varying course of events". 52 Their

${ }^{47}$ Gabriel (1989b), p. ix. Up to the end of the nineteenth century, Bolzano's anti-psychologism remained largely unknown.

${ }^{48}$ Russell (1897a), p. 190.

${ }^{49}$ Russell (1903), § 426.

${ }^{50}$ Cf. e.g. Höffding (1896), ii, pp. 574 ff..

${ }^{51}$ Manser (1984), p. 309) Manser is, of course, wrong when he claims that Lotze did not accept the context principle; so that the latter was even against his atomism. Cf. Manser (1984), p. 310.

${ }^{52}$ Lotze (1856/64) iii, p. 466; Lotze (1885), ii, p. 579. 
independence as fixed points of the ontological discourse is at hand, however, only "up to the moment of their [of individual things] being again perceived by us. This being perceived is itself nothing but a new relation which is added to, or dissolves, the old ones." ${ }^{, 53}$

All in all, it can be said that to Lotze the priority of things over the relations in which they enter is epistemological, while the priority of the relations over the things is ontological: "In order to think the existence of things [as different from perceiving them] one must grasp [them as independent]. ${ }^{~} 54$ However, this does not mean that they are independent. In this sense Lotze claimed that "the existence of everything presupposes the existence of some other to which it must be related". ${ }^{55}$ The things are in the net of these potential relations; in a "vault [Gewölbe] of mutually related things"; or of "tissue of orders".

\subsection{Lotze's dialectics}

The position of Lotze on the controversy holism/atomism can be only seen as unclear if one fails to understand his peculiar method he himself called "dialectical", expressly referring to Hegel. ${ }^{56}$ This explains why "there are some passages [in Lotze's writings] in which he does seem conscious of the contradictions and [nevertheless] attempts to mediate between the two", not to eliminate one of them. ${ }^{57}$

Some authors appreciate these traces of Hegel's dialectics in Lotze's writings rather negatively. Thus Eduard von Hartmann complains that "there are scarcely a 'yes' by Lotze, which is not sublated at another place by a 'no' ". ${ }^{58}$ Yet other philosophers, George Santayana was one of them, turned attention to the fact that despite the apparent contradictions, Lotze's system remained astonishingly consistent. How can this be?

The point is that Lotze did not copy Hegel's dialectics mot à mot - he developed it further. Lotze, more precisely, enriched it through the method of eclecticism, already discussed (in $\S$ 1). Through it, Hegel's dialectics turns into a method of appeasing philosophical dilemmas.

In particular, Lotze assumed that the conflicting philosophical conceptions often correspond to different philosophical perspectives. The same is true of different, prima facie con-

\footnotetext{
${ }^{53}$ Ibid., p. 467; p. 580.

${ }^{54}$ Lotze (1856/64), iii, p. 471; Lotze (1885), ii, p. 584.

${ }^{55}$ Ibid., p. 472; p. 585. Cf. with 2.012 of Wittgenstein's Tractatus: "If a thing can occur in a state of affairs, the possibility of the state of affairs must be written into the thing itself."

${ }^{56}$ Cf. Lotze (1841), p. 320.

${ }^{57}$ Kuntz (1971), p. 34.

${ }^{58}$ Hartmann (1888), p. 147.
} 
tradicting aspects of Lotze's philosophy. So the idealist monism of his system is rather "psychological, it is a personal manner of reading things, a poetic intuition of the cosmic life". ${ }^{59}$ On the contrary, its atomism is scientific — another stance Lotze adopted.

Especially intriguing — but also tricky — is the fact that Lotze often unfolded different faces of his apparently conflicting intuitions in the course of one and the same investigation. Thus he consciously began his ontological studies with pluralistic realism only to end them with monistic idealism.

The use of the dialectical method made Lotze - similarly to Wittgenstein later ${ }^{60}-\mathrm{a}$ "slippery fish". His position is characteristically difficult to state and also hard to criticise. Exactly this fact misled Russell in his interpretation of Lotze's theory of space.

\section{LOTZE AND MOORE}

As already mentioned in $\S 1$, similarly to Russell, G. E. Moore knew Lotze's work very well. It does not come as surprise that in many respects the philosophies of Lotze and Moore show affinities.

\subsection{General approach}

Above all, there is a family resemblance between the following four points of Lotze's approach in philosophy and the approach of Moore:

(i) Today scarcely anyone remembers that Lotze was anxious to be in accord with common sense (die gewöhnliche Meinung). This was a leading principle for his philosophy.

(ii) Lotze was convinced that "the logical reasoning is nothing but a critical elucidation, or working-up, of the ordinary course of presentations". ${ }^{61}$

(iii) Lotze's understood his approach as one that clears up language-usage and common sense, for example, of the word "is".

(iv) The very stance of Lotze's philosophy was down-to-earth realism, directed against any form of speculation.

\footnotetext{
${ }^{59}$ Santayana (1889), p. 155.

${ }^{60}$ This is another point of kinship between Lotze and Wittgenstein. Cf. $\S 8$ for basic similarities between them.

${ }^{61}$ Lotze (1843), p. 66.
} 
Beyond matters of a general approach to philosophy, Lotze was also close to Moore theoretically. This claim can be supported referring to Moore's programme in Principia Ethica for finding a logical solution to ethical problems.

Moreover, just like Moore later, Lotze accepted that his system of metaphysics is based on data and their interconnections. He, however, said nothing about the nature of the data themselves; for him they are "indefinables". ${ }^{2}$ This term was extensively used by Moore, starting with Principia Ethica, where he accepted as indefinables good and bad, ${ }^{63}$ and finishing with the introduction of the term sense-data in epistemology. ${ }^{64}$

\subsection{Moore's theory of judgment}

A more specific line of theoretical influence of Lotze on Moore can be tracked down in Moore's Relational Theory of Judgment as advanced in the paper "On the Nature of Judgment" in which he claims: "A proposition is a synthesis of concepts, together with a specific relation between them." ${ }^{, 65}$

Our claim is that Moore's Relational Theory of Judgment ${ }^{66}$ can be seen as a paraphrase of Lotze's theory of judgment's content as an interrelation of things or pieces of facts (sachliches Verhalten). According to this conception, a judgment expresses a relation (Verhältnis) between the contents of two presentations; i.e. a relation between two factual pieces of reality which are the content of the judgment. To understand a sentence is to understand a "factual relation of presented contents" (sachliches Verhältnis der vorgestellten Inhalte).

This theory was the outcome of Lotze's criticism of the conventional discrimination between substance and attribute in metaphysics. Instead, he spoke of "tying up [Verknüpfung] of the multiple until [receiving] the general" of the "substance" already in his first Logic. ${ }^{67}$ Later

\footnotetext{
${ }^{62}$ Cf. Höffding (1896), ii, p. 578.

${ }^{63}$ Moore (1903), p. 5.

${ }^{64}$ Moore introduced the term "sense-data" in his (1909/10).

${ }^{65}$ Moore (1899), p. 64.

${ }^{66}$ Quite recently, it was suggested that Moore's theory of judgment was decisively influenced by Brentano's analytical psychology, which was made popular at Cambridge through Stout (cf. Bell 1999). Unfortunately, this author forgets that much before Berntano, elements of analytical psychology had been developed by Lotze. It must also be remembered that Brentano was a student of Lotze's elder fellow objectivist-revolutionary in philosophy, Adolf Trendelenburg.

${ }^{67}$ Lotze (1843), p. 85.
} 
on, Lotze spoke of supplementing (Ergänzung) ${ }^{68}$ the elements in a substance, and of substances' assistance (Förderung) of the elements. ${ }^{69}$

The fact that Lotze embraced a relational theory of judgment is supported by his claim that the copula "connects the general and the particular in the concept only in so far as it keeps them apart". ${ }^{70}$ He called their connection (Verknüpfung) "logical relation". It is a logical form. In contrast, the connection between substance and accident is a "metaphysical relation". ${ }^{71}$

Moore's Relational Theory of Judgment was later developed by Russell into a Multiple Relation Theory of Judgment. ${ }^{72}$ In it Russell abolished the Moorean propositions completely, reducing them to their terms plus the interrelation between the terms. Russell's theory, nevertheless, preserved the relational character of judgments, which was the core of Moore's theory. According to Russell, the belief or judgment $(J)$ is a relation between the subject $(S)$, the form $(F)$, and the objects of judgment or belief $\left(x_{1}, x_{2}, \ldots x_{\mathrm{n}}\right)$. The formal script of this apprehension is: $J\left(S, F, x_{1}, x_{2}, \ldots x_{\mathrm{n}}\right){ }^{73}$ It is of special interest for our study that, in fact, it repeats Lotze's formula of composed "true wholes", $M=\varphi$ [A B R], where $\varphi$ presents the kind of connection between its elements $\mathrm{A}, \mathrm{B}$, and $\mathrm{R}$ ( $\mathrm{R}$ is the sum of all implicit elements of $\mathrm{M}$ ). What Lotze's formula lacks is Russell's subject $\mathrm{S}$.

\section{LOTZE AND WITTGENSTEIN}

The influence of Lotze on Wittgenstein was rather indirect - it was exercised above all through his teachers Russell and Frege. A possible bridge to Lotze was also Samuel Alexander with whom Wittgenstein stayed in contact while in Manchester (1909-11), before he came up to Cambridge. Alexander's Space, Time and Deity, in particular, delivered as "Gifford Lec-

\footnotetext{
${ }^{68}$ This conception was developed by Frege in his theory of judgment as a completing of the function with the argument.

${ }^{69}$ Cf. Lotze (1879), § 70. This point shows that Russell's interpretation of Lotze's logic as implying "that all propositions consist in the ascription of a predicate to subject, and that this ascription is not a relation" (Russell 1903, § 426) was inaccurate. Cf. § 6.3.

${ }^{70}$ Lotze (1843), p. 86.

${ }^{71}$ Ibid., p. 88. This conception is connected with Lotze's theory of different kinds of states of affairs. See on this point chapter 7 .

${ }^{72}$ Already P. G. Kuntz has noted that Lotze's "theory of truth ... was later developed conspicuously by Bertrand Russell”. Kuntz (1971), p. 29.

${ }^{73}$ Russell (1984), p. 144.
} 
tures" (1916-18), shows the considerable influence of Lotze. Another possible source of Lotze's influence on Wittgenstein was William James. Indeed, it is well-documented that Wittgenstein read The Varieties of Religious Experience.

Of course, of utmost importance is the influence Lotze had on Wittgenstein received through Frege. It was, above all, connected with introducing the act of will in logic in the concept of asserting of propositions. However, since in this chapter we do not investigate the relation between Lotze and Frege, we will abstain from discussing it.

Lotze's non-Fregean influences on Wittgenstein can be traced back mainly in three directions:

\subsection{States of affairs and general logical form}

Wittgenstein ontology was in many respects a continuation-modification — of Russell's ontology. ${ }^{74}$ This explains why many points of relatedness between Lotze's and Russell's ontology, which we discussed above, appear in Wittgenstein in a new form.

Above all, both Lotze's Logic (1874) and Wittgenstein's Tractatus used the concept of states of affairs (Sachverhalte) as basic concept in logic and ontology. Wittgenstein defines states of affairs as "a combination of objects" that "fit into one another like the links of a chain"; ${ }^{75}$ Lotze defines them as "a concatenation of objects". ${ }^{76}$

In the Tractatus Wittgenstein also claims that all the various combinations of forms of objects give rise to an infinite number of states of affairs. Further, different states of affairs are concatenated in complex states of affairs, in the same way in which objects and forms of objects are concatenated in states of affairs. The concatenations in complex states of affairs are a kind of tying up of logical forms of individual states of affairs.

Wittgenstein's proposition, however, is also a combination of forms. The acceptance of the same principle of compositionality in both states of affairs, propositions, and complex propositions, explains the otherwise enigmatic claim in the Tractatus that there is just one logical constant. ${ }^{77}$ There is not a logical constant active between atomic propositions, and another logical constant (or some other logical operator) active in atomic propositions. This one logical constant is employed in the (only) general form of propositions which is "what all propositions by their very nature, had in common with all another" (5.47). The general logical form

\footnotetext{
${ }^{74}$ Cf. Landini (2007).

${ }^{75}$ Wittgenstein (1922), 2.01, 2.03.

${ }^{76}$ Lotze (1879), § 117.

${ }^{77}$ Cf. Milkov (2001), p. 404.
} 
reads: "The things hang together so-and-so [es verhält sich so und so]"78 (4.5) and denotes how things stand in relation to all other things.

It is astonishing how close this solution of Wittgenstein is to that of Lotze. Indeed, Lotze's first principle - "that the determination of every existing thing depends on its position in a multitude" (substance, whole, states of affairs) - was also founded on the "general logical form of composition of series". ${ }^{79}$ Exactly like Wittgenstein in the Tractatus, Lotze assumed that there is one pattern of composition in both mind and matter. ${ }^{80}$

\subsection{Panpsychism}

Lotze accepts that "the law that makes the substantial unity of a thing is an individual law; it is conceived on the analogy of human character, or of aesthetic unity like melodies" ${ }^{81}$ This position makes it understandable why the elements of the states of affairs in Lotze's microcosmology take care (kümmern sich) of one another, ${ }^{82}$ they have fate (Schicksale) and sensitivity (Reizbarkeit). ${ }^{83}$ These are clear elements of panpsychism. ${ }^{84}$

Now, if we consider Wittgenstein's microcosmology-according to which "I am my world. (The microcosm.) ${ }^{n 55}$-in more detail, we shall see that it contains a chain of assumptions, all of them with a clear panpsychic colouring:

(i) In 1916 Wittgenstein discussed the expression: "as I can infer my spirit (character, will) from my physiognomy, so I can infer the spirit (will) of each thing from its physiognomy." Similarly, the facts have features, "in the sense in which we speak of facial features". These

\footnotetext{
${ }^{78}$ My translation from the German. A similar translation is suggested in Garver (1994), p. 134.

${ }^{79}$ Misch (1912), p. xxxii; italics mine.

${ }^{80}$ That the problem of compositionality found by Wittgenstein and Lotze the same solution is also obvious from the common use of the term of "[logical] scaffolding”. Cf. Lotze (1874), § ix; Wittgenstein (1922), 3.42, 4.023. On Wittgenstein's concept of scaffolding see Milkov (2001).

${ }^{81}$ Santayana (1971), p. 183; italics mine.

${ }^{82}$ Lotze (1879), § 69.

${ }^{83}$ Ibid., $\$ 70$.

${ }^{84}$ On Lotze's panpsychism see Kuntz (1971), p. 34. On this point Lotze was also followed by William James and A. N. Whitehead.

${ }^{85}$ Wittgenstein (1922), 5.63.

${ }^{86}$ Wittgenstein (1979), p. 84. Wittgenstein was only critical of the word "infer" here: We infer only in logic, not in natural science, and of course not in general discourse. He insisted that it would be better to say: "As I can see my spirit in my physiognomy, .... ."
} 
are their prototypes. ${ }^{87}$ Panpsychic elements were also made valid in language: "Every word has a different character in different contexts, [but] at the same time there is one character it always has: a single physiognomy. It looks at us." ${ }^{, 8}$

(ii) Wittgenstein accepted that every animal natural kind has its own physiognomy. Now, since animals, in opposition to things, are active, the idiosyncrasy of their physiognomy finds expression in the idiosyncrasy of their life. Thus every animal natural kind has a peculiar form of life: There is a human form of life, a lion form of life, etc.

(iii) In a more abstract perspective, each individual of a specific animal natural kind has its own form of life. Now, since life and world are one, ${ }^{89}$ the inner content of such "primitive" form of life is a microcosm (the micro-world); its outer limit is a macrocosm (the macro-world). This position practically echoes Lotze's concept of microcosm. ${ }^{90}$

\subsection{Logic, ethics and aesthetics have one source}

In the Tractatus ethics, aesthetics, and logic have their roots in the experience sub specie aeternitatis in which we see the objects under scrutiny as a limited whole. In logic such a whole is the "perfectly" analysed logical formula; in aesthetics the "perfect work of art"; in ethics the "good life". These wholes are contemplated; they can be shown, not articulated.

Our claim is that the common source of ethics, aesthetic and logic was first pointed at by Lotze who found its roots in the fact that they all advance products which have value. This conception of Lotze was further developed by the South Western Neo-Kantians, especially by Wilhelm Windelband, who was his closest student. Windelband set out that the knowing of the world did not occur sub specie aeternitatis. We have such knowledge only of things that have value, not merely an existence. ${ }^{91}$

This is exactly what Wittgenstein said on the 7th of October $1916 .{ }^{92}$ We see sub specie aeternitatis the work of art; the good life; and the logical symbol. ${ }^{93}$

\footnotetext{
${ }^{87}$ Wittgenstein (1922), 4.1221.

${ }^{88}$ Wittgenstein (1953), p. 81.

${ }^{89}$ Wittgenstein (1922), 5.641.

${ }^{90}$ Cf. Milkov (2006).

${ }^{91}$ Cf. Windelband (1883), p. 343.

${ }^{92}$ Cf. Wittgenstein (1979), p. 83.

${ }^{93}$ Cf. Milkov (2004).
} 


\section{REFERENCES}

Bauch, Bruno. 1918. "Lotze's Logik und ihre Bedeutung im deutschen Idealismus", Beiträge zur Philosophie des deutschen Idealismus 1: 45-58.

Bell, David. 1999. “The Revolution of Moore and Russell: A Very British Coup?” in A. O'Hear (ed.), German Philosophy since Kant, Cambridge: Cambridge University Press, pp. 137-66.

Collingwood, R. G. 1939. An Autobiography, Harmondsworth: Penguin (2nd edn 1944).

Cuming, Agnes. 1917. "Lotze, Bradley, and Bosanquet". Mind 26: 162-70.

Dummett, Michael. 1973. Frege. Philosophy of Language, London: Duckworth.

—. 1981. The Interpretation of Frege's Philosophy, London: Duckworth.

1991. Frege. Philosophy of Mathematics, London: Duckworth.

Gabriel, Gottfried. 1986. "Frege als Neukantianer", Kant-Studien 77: 84-101.

- 1989a. "Einleitung des Herausgebers. Lotze und die Entstehung der modernen Logik bei Frege", in H. R. Lotze, Logik, Erstes Buch. Vom Denken, Hamburg: Meiner, pp. xi-xliii.

_ 1989b. "Einleitung des Herausgebers: Objektivität, Logik und Erkenntnistheorie bei Lotze und Frege", in H.

R. Lotze, Logik, Drittes Buch. Vom Erkennen (Methodologie), Hamburg: Meiner, pp. xi-xxxiv.

Garver, Newton. 1994. This Complicated Form of Life: Essays on Wittgenstein, Chicago: Open Court.

Griffin, Nicholas. 1991. Russell's Idealistic Apprenticeship, Oxford: Clarendon Press.

. 1996. "F. H. Bradley's Contribution to the Development of Logic", in James Bradley (ed.), Philosophy After

F. H. Bradley, Bristol: Thoemmes Press, pp. 195-230.

Hartmann, Eduard von. 1888. Lotzes Philoeophie, Leipzig: Friedrich.

Heidegger, Martin. 1978. Frühe Schriften, Frankfurt: Klostermann.

Höffding, H. 1896. Geschichte der neueren Philosophie, 2 vols., Leipzig: Reisland.

Kneale, W. and M. 1962. The Development of Logic, Oxford: Clarendon Press.

Kroneberg, M. 1899, Moderne Philosophen. Porträts und Charakteristiken, München: Beck.

Kuntz, P. G. 1971. "Rudolf Hermann Lotze, Philosopher and Critic." Introduction to Santayana, pp. 3-94.

Lotze, Rudolf Hermann. 1841. Metaphysik, Leipzig: Weidmann.

- 1843. Logik, Leipzig: Weidmann.

— 1847. Über Bedingungen der Kunstschönheit, Göttingen: Vandenhoeck und Ruprecht.

—. 1856. Microcosmus, 3 vols., Leipzig: Hirzel (1856-64).

1857. Streitschriften. Heft 1. Leipzig: Hirzel.

1874. Logik, Leipzig: Hirzel.

1879. Metaphysik, Leipzig: Hirzel.

1883. Grundzüge der Logik und Encyclopädie der Philosophie, Leipzig: Hirzel. 4th edn. 1912.

1884. System of Philosophy (B. Bosanquet et al., Trans.) Oxford: Clarendon Press.

1885. Microcosmus. An Essay Concerning Man and his Relation to the World. 2 vols. Trans. E. Hamilton and

E. E. Constance Jones. New York: Scriber and Welford.

- 1888. Metaphysic (B. Bosanquet et al., Trans.) (2d ed.). Oxford: Clarendon Press.

1989. Logik. Drittes Buch. Vom Erkennen, Hrsg. G. Gabriel, Hamburg: Meiner.

Manser, Anthony. 1983. Bradley's Logic, Oxford: Blackwell.

. 1984. "Bradley and Frege", in A. Manser and Guy Stock (eds.), The Philosophy of F. H. Bradley, Oxford:

Clarendon Press, pp. 303-17.

McGuinness, B. F. 1966. "The Mysticism of the Tractatus", The Philosophical Review 75: 305-28.

- 2002. Approaches to Wittgenstein: Collected Papers, London: Routledge.

Milkov, Nikolay. 1997. The Varieties of Understanding: English Philosophy Since 1898, 2 vols., Frankfurt: Peter Lang.

_. 2001. "Tractarian Scaffoldings", Prima philosophia 14: 399-414.

— 2004. "Ist Wittgensteins Tractatus in irgendeinem Sinne mystisch?”, Theologie und Philosophie 79: 511-26.

—. 2006. "Hermann Lotze's Microcosm", in: A.-T. Tymieniecka (ed.), Islamic Philosophy and Occidental Phenomenology on the Perennial Issue of Microcosm and Macrocosm. Berlin: Springer, pp. 41-65.

Misch, Georg. 1912. "Einleitung", in H. R. Lotze, Logik, 2nd ed., Hrsg. von G. Misch, Leipzig: Meiner, pp. $\mathrm{v}-\mathrm{cxxiii}$.

Moore, G. E. "On the Nature of Judgement", in idem, The Early Essays, ed. by T. Regan, Philadelphia: Temple University Press, pp. 59-80.

—. 1903. Principia Ethica, Cambridge: Cambridge University Press.

—. 1909-10. "The Subject-matter of Psychology", Proceedings of the Aristotelian Society 10: 36-62.

1942. "An Autobiography", in P. A. Schilpp (ed.), The Philosophy of G. E. Moore, Evanston (Ill.): North-western University Press, 1-39.

Mulligan, K., Simons, P., and Smith, B. 1984. "Truth-Makers", Philosophy and Phenomeno logical Research 44: 287-321.

Nicholson, Peter. 1990. The Political Philosophy of the British Idealists, Cambridge: Cambridge University Press. Passmore, John. 1966. A Hundred Years of Philosophy; 2nd edn., Harmondsworth: Penguin. 
. 1995. "Editing Russell's Papers: A Fragment of Institutional History", Grazer Philosophische Studien 49: 189-205.

Perry, Ralf Barton. 1935. The Thought and Character of William James, Boston: Little, Brown, and Co.

Peterson, Donald. 1990. Wittgenstein's Early Philosophy. Three Sides of the Mirror, New York: Harvester.

Russell. Bertrand. 1895. "Review of Heymans Die Gesetze und Elemente des wissenschaftlichen Denken", in idem, Collected Papers, vol. 2, pp. 35-43.

- 1897. An Essay on the Foundations of Geometry, Cambridge: At the University Press.

1903. The Principles of Mathematics, London: Allen \& Unwin.

1910. (together with Alfred N. Whitehead) Principia Mathematica, 3 vols. (1910-13), Cambridge: Cambridge University Press.

—. 1917. "On Scientific Method in Philosophy", in idem, Mysticism and Logic, London: Allen \& Unwin. 2nd. ed. 1963.

- 1984. Theory of Knowledge. The 1913 Manuscript, ed. E. R. Eames, London: Allen \& Unwin

Santayana, George. 1971. Lotze's System of Philosophy, ed. P. G. Kuntz, Bloomington: Indiana University Press (composed in 1889).

Schütz, Alfred. 1932. Der sinnhafte Aufbau der sozialen Welt: eine Einleitung in die verstehende Soziologie, Wien: Springer.

Sluga, Hans. 1980. Gottlob Frege, London: Routledge \& Kegan Paul

Smith, Barry. 1987. "On the Cognition of States of Affairs", in K. Mulligan (ed.), Speech Act and Schverhalt. Reinach and the Foundation of Realist Phenomenology, Dordrecht: Nijhoff, pp. 189-225.

Stumpf, Carl. 1910. Philosophische Reden und Vorträge, Leipzig: Barth.

Sweet, William. 1995. "Was Bosanquet a Hegelian?”, Bulletin of the Hegel Society of Great Britain, 31: 39-60.

Taylor, A. E. 1925. "F. H. Bradley", Mind 34: 1-12.

Thomas, Geoffrey. 1987. The Moral Philosophy of T. H. Green, Oxford: Clarendon Press.

Windebnand, Wilhelm. 1882. "Was ist Philosophie?", in idem 1884, i, pp. 1-54.

- 1883. "Sub specie aeternitatis", in idem 1884, ii, pp. 333-45.

1884. Präludien (9th ed.), 2 vols., Tübingen: Mohr, 1922.

Wittgenstein, Ludwig. 1922. Tractatus Logico-Philosophicus, tr. Ogden and Ramsey, London: Allen \& Unwin.

- 1953. Philosophical Investigations, tr. G. E. M. Anscombe, Oxford: Blackwell.

1979. Notebooks 1914-1916, Oxford: Blackwell; 2nd edn.

Wundt, Wilhelm. 1877. "Philosophy in Germany", Mind, n.s., 2: 493-513. 